\title{
Chemical Stability of Cd(II) and Cu(II) Ionic Imprinted Amino-Silica Hybrid Material in Solution Media
}

\author{
Buhani $^{a}$, Narsito ${ }^{b}$, Nuryono ${ }^{b}$, Eko Sri Kunarti ${ }^{b}$ \\ ${ }^{a}$ Department of Chemistry, Faculty of Mathematic and Natural Sciences, \\ University of Lampung, Lampung, Indonesia \\ email: buhani_s@yahoo.co.id \\ ${ }^{\mathrm{b}}$ Department of Chemistry, Faculty of Mathematic and Natural Sciences, \\ Gadjah Mada University, Yogyakarta, Indonesia
}

\begin{abstract}
Chemical stability of $\mathrm{Cd}(\mathrm{II})$ and $\mathrm{Cu}(\mathrm{II})$ ionic imprinted hybrid material of ( $i$-Cd-HAS and $i$-Cu-HAS) derived from silica modification with active compound (3-aminopropyl)-trimethoxysilane (3-APTMS) has been studied in solution media. Stability test was performed with $\mathrm{HNO}_{3} 0.1 \mathrm{M}(\mathrm{pH} 1.35)$ to investigate material stability at low $\mathrm{pH}$ condition, $\mathrm{CH}_{3} \mathrm{COONa} 0.1 \mathrm{M}(\mathrm{pH}$ 5.22) for adsorption process optimum $\mathrm{pH}$ condition, and in the water $(\mathrm{pH}$ 9.34) for base condition. Material characteristics were carried out with infrared spectrophotometer (IR) and atomic absorption spectrophotometer (AAS). At interaction time of 4 days in acid and neutral condition, $i$-Cd-HAS is more stable than $i$-Cu-HAS with \% Si left in material 95.89 $\%$ (acid media), $43.82 \%$ (close to neutral), and $9.39 \%$ (base media).
\end{abstract}

Keywords: chemical stability, amino-silica hybrid, ionic imprinting technique.

Pendahuluan

Dalam beberapa tahun terakhir ini, sintesis material hibrida organik-anorganik dalam berbagai bidang cukup banyak dilakukan. Salah satu pemanfaatan material tersebut adalah studi dan aplikasinya sebagai adsorben logam berat yang berasal dari modifikasi padatan anorganik dengan gugus aktif senyawa organik (Alcantara et al., 2007; Cui et al., 2007; Hajiaghababei et al., 2011). Keberhasilan penggunaan material hibrida organik-anorganik sebagai adsorben logam sangat ditentukan oleh kestabilan kimia material dalam larutan dan kemampuannya mengadsorpsi logam sebagai target.
Silika gel merupakan salah satu padatan anorganik yang banyak dimodifikasi dengan senyawa organik untuk menghasilkan material yang memiliki karakteristik sebagai adsorben yang lebih optimal dibandingkan dengan silika tanpa modifikasi. Hal ini dikarenakan silika gel merupakan padatan pendukung yang ideal untuk proses adsorpsi karena stabil pada kondisi asam, non swelling, memiliki karakteristik pertukaran massa yang tinggi, berpori, dan memiliki luas permukaan yang spesifik serta memiliki daya tahan tinggi terhadap panas. Selain itu silika gel memiliki situs aktif berupa gugus silanol ( $=\mathrm{SiOH}$ dan siloksan $(\equiv \mathrm{Si}-\mathrm{O}-\mathrm{Si} \equiv)$ di permukaan (Camel, 2003; Jiang et al., 2006). 
Kelemahan penggunaan silika gel sebagai adsorben adalah rendahnya efektivitas adsorpsi silika terhadap ion logam. Hal ini disebabkan oleh rendahnya kemampuan oksigen (silanol dan siloksan) sebagai donor pasangan elektron yang berakibat lemahnya ikatan ion logam pada permukaan silika. Berbagai upaya telah dilakukan untuk memperbaiki kelemahan silika akibat ikatan langsung oksigen pada silika, antara lain dengan memodifikasi permukaan silika menggunakan senyawa organik yang mengandung ligan yang secara khusus diharapkan berinteraksi dengan ion logam.

Dari beberapa penelitian terdahulu penggunaan gugus amin $\left(-\mathrm{NH}_{2}\right)$ sebagai agen pemodifikasi cukup banyak dilakukan, karena gugus tersebut diharapkan dapat meningkatkan kemampuan adsorpsi material untuk semua jenis ion logam (Chiron et al., 2003; Buhani et al., 2009). Atom N diklasifikasikan sebagai atom donor yang bersifat keras, tetapi atom $\mathrm{N}$ lebih disukai dibandingkan dengan atom $\mathrm{O}$ untuk kelompok asam-asam lunak, ini dikarenakan rendahnya elektronegativitas atom $\mathrm{N}$ dibandingkan dengan atom $\mathrm{O}$ dan memiliki karakter netral yang lebih disukai dari $\mathrm{O}$ untuk pembentukan kompleks dengan asam lunak dan madya seperti ion $\mathrm{Cd}(\mathrm{II})$ dan $\mathrm{Cu}(\mathrm{II})$ (Hyvönen, 2008). Dengan demikian peningkatan kapasitas adsorpsi material hasil modifikasi dapat tercapai, karena adanya kesesuaian atom donor dengan ion target dalam proses adsorpsi.

Selain peningkatan kapasitas adsorpsi, maka selektivitas adsorben terhadap logam target juga perlu ditingkatkan. Salah satu teknik dalam pembuatan adsorben agar bersifat selektif terhadap ion logam adalah teknik pembuatan cetakan ion logam yang akan dijadikan target dalam proses adsorpsi. Pada proses pencetakan ion selektivitas adsorpsi ion logam dapat tercapai karena pada saat sintesis polimer terdapat ion logam yang berperan sebagai templat dan monomer yang mengandung gugus fungsional. Pelepasan ion templat dari matriks polimer akan menyebabkan penataan polimer tercetak ion menjadi selektif terhadap ion templat atau molekul dari komponen lain dalam sampel (Zhao et al., 2007; Zhai et al., 2008, Buhani et al., 2010).

Pada penelitian ini telah dilakukan modifikasi silika dengan teknik sol gel dengan menggunakan prekursor TEOS disertai dengan proses pencetakan ion $\mathrm{Cd}(\mathrm{II})$ dan $\mathrm{Cu}$ (II) pada hibrida organo-silika. Untuk mengetahui keberhasilan sintesis material hibrida aminosilika tercetak on $\mathrm{Cd}(\mathrm{II})$ dan $\mathrm{Cu}(\mathrm{II})$, maka telah dilakukan uji stabilitas kimia material dalam media larutan pada kondisi asam, sedikit netral, dan basa. 


\section{Tujuan penelitian}

Mengetahui stabilitas kimia adsorben hibrida amino-silika tercetak ion $\mathrm{Cd}(\mathrm{II})$ dan $\mathrm{Cu}(\mathrm{II})$ dalam media larutan pada kondisi asam, sedikit netral, dan basa.

\section{Metode Penelitian}

\section{Bahan dan alat}

Bahan yang digunakan adalah 3APTMS, berasal dari Aldrich. TEOS, $\mathrm{CdCl}_{2} \cdot \mathrm{H}_{2} \mathrm{O}, \quad \mathrm{CuCl}_{2} \cdot 2 \mathrm{H}_{2} \mathrm{O}, \quad \mathrm{Na}_{2}$ EDTA, $\mathrm{CH}_{3} \mathrm{COOH}$, etanol, $\mathrm{CH}_{3} \mathrm{COONa}, \mathrm{HNO}_{3}$, kertas saring Whatman 42, dan kertas indikator Universal berasal dari E-Merck. $\mathrm{HCl}$ dan $\mathrm{NaOH}$ dari Alba.

Peralatan yang digunakan adalah peralatan gelas, timbangan analitik, alat penggerus (lumpang dan mortar), ayakan ukuran 200 mesh, pemanas, pengaduk magnet, sentrifugator, dan $\mathrm{pH}$ meter (Orion 4 Star). Spektrofotometer serapan atom (SSA) Model Perkins Elmer 3110 dan spektrofotometer IR Prestige-21 Shimadzu masing-masing digunakan untuk analisis logam dan identifikasi gugus fungsional.

\section{Prosedur Penelitian}

\section{Sintesis material $\boldsymbol{i}$-Cd-HAS dan $\boldsymbol{i}$-Cu-HAS}

Pada sintesis HAS tercetak ionik Cd(II) dan $\mathrm{Cu}$ (II) dengan menggunakan senyawa 3APTMS, larutan yang akan diinteraksikan dibuat menjadi dua bagian, terdiri atas larutan A yang berisi $5 \mathrm{~mL}$ TEOS dan air dimasukkan dalam gelas plastik serta ditambahkan larutan $\mathrm{HCl} 1 \mathrm{M}$ sampai $\mathrm{pH}$ 2, kemudian diaduk dengan pengaduk magnet selama 30 menit. Larutan B berisi $5 \mathrm{~mL}$ etanol dengan masing-masing 0,30198 gram $\mathrm{CdCl}_{2} \cdot \mathrm{H}_{2} \mathrm{O}$ dilarutkan dengan pengadukan untuk sintesis $i$-Cd-HAS. Untuk sintesis $i$-Cu-HAS digunakan 0,17048 gram $\mathrm{CuCl}_{2} \cdot 2 \mathrm{H}_{2} \mathrm{O}$ dilarutkan dengan pengadukan. Selanjutnya ditambah dengan senyawa 3APTMS masing-masing sebanyak $1 \mathrm{~mL}$ diaduk sampai homogen (1 jam). Larutan A dicampur dengan larutan $\mathrm{B}$ dengan pengadukan menggunakan pengaduk magnet selama 30 menit. Gel yang terbentuk dibiarkan semalam, kemudian dibilas dengan campuran air/etanol 60/40 \%, dilanjutkan dengan merendam gel selama 24 jam dalam larutan $\mathrm{Na}_{2}$ EDTA $0,1 \mathrm{M}$ dan diaduk selama 30 menit dalam $\mathrm{HCl}$ 0,5 M. Selanjutnya material dinetralkan dengan akuades sampai $\mathrm{pH} \approx 7$, kemudian dikeringkan dalam oven selama 6 jam pada temperatur $60^{\circ} \mathrm{C}$ dan digerus sampai berukuran 200 mesh.

\section{Stabilitas kimia}

Untuk mengetahui stabilitas kimia material $i$-Cd-HAS dan $i$-Cu-HAS, sebanyak 0,1 gram material dimasukkan ke dalam $100 \mathrm{~mL}$ masing-masing pelarut, yaitu larutan $\mathrm{HNO}_{3}$ 0,1 $\mathrm{M}(\mathrm{pH} 1,35), \mathrm{CH}_{3} \mathrm{COONa}$ 0,1 M (pH 5,22), dan air (pH 9,34) dengan variasi waktu 1 - 4 hari. Kadar Si yang terlarut dalam filtrat dianalisis 
dengan menggunakan SSA. Endapan yang tersisa dikeringkan dan dianalisis dengan spektrofotometer IR. Presentase Si yang tersisa dalam material tercetak ion dihitung berdasarkan persamaan; \% Si tersisa $=[\mathrm{Si}]_{\mathrm{t}} /[\mathrm{Si}]_{\mathrm{o}}$ x 100, dimana [Si] adalah konsentrasi Si awal dalam material tercetak ion dan $[\mathrm{Si}]_{\mathrm{t}}$ adalah konsentrasi $\mathrm{Si}$ terlarut masing-masing pada waktu t dalam $\mathrm{mg} \mathrm{L}^{-1}$.

\section{Hasil dan Pembahasan}

Salah satu parameter untuk menentukan kualitas material tercetak ion yang dihasilkan adalah stabilitas kimia material dalam media larutan. Pada penelitian ini media larutan yang digunakan untuk menentukan stabilitas kimia $i$ Cd-HAS dan $i$-Cu-HAS adalah larutan $\mathrm{HNO}_{3}$ $0,1 \mathrm{M}(\mathrm{pH} 1,35)$ yang bertujuan mengetahui stabilitas material pada kondisi $\mathrm{pH}$ rendah, larutan $\mathrm{CH}_{3} \mathrm{COONa} 0,1 \mathrm{M}(\mathrm{pH}$ 5,22) untuk kondisi $\mathrm{pH}$ optimum proses adsorpsi, dan di dalam air ( $\mathrm{pH} 9,34)$ untuk kondisi sedikit basa.

Pada Gambar 1 dapat diamati bahwa jumlah Si tersisa sampai waktu interaksi selama 4 hari paling banyak untuk media larutan $\mathrm{HNO}_{3}$ $(\mathrm{pH}=1,35)$. Hal ini menunjukkan bahwa material sangat stabil pada kondisi asam. Protonasi gugus amina secara signifikan meningkatkan stabilitas material dalam medium larutan air. Kemungkinan lain adanya protonasi membatasi kontak air dengan material HAS tercetak ion $\mathrm{Cd}(\mathrm{II})$ dan $\mathrm{Cu}$ (II).

Senyawa aktif 3-APTMS yang terdapat pada material tercetak ionik $\mathrm{Cd}(\mathrm{II})$ ada dalam dua bentuk, bentuk amina bebas tidak terprotonasi $\left(\equiv \mathrm{Si}-\mathrm{C}_{3} \mathrm{H}_{6}-\mathrm{NH}_{2}\right)$ dan bentuk ion zwitter $\left(\equiv \mathrm{SiO}^{-},{ }^{+} \mathrm{H}_{3} \mathrm{NC}_{3} \mathrm{H}_{6}-\mathrm{Si} \equiv\right)$ (Etienne and Walcarius, 2003).
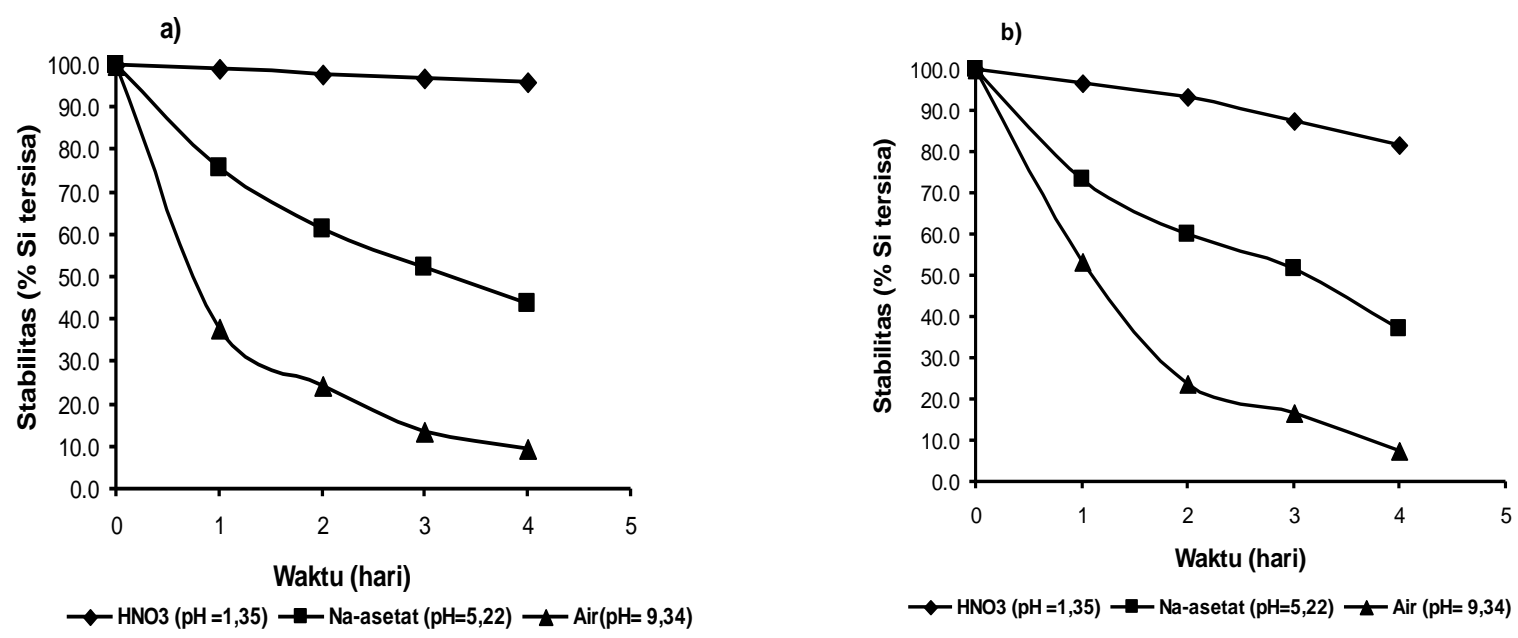

Gambar 1. Hubungan antara \% Si tersisa dengan waktu interaksi dalam media larutan pada a) $i$-Cd-HAS dan b) $i$-Cu-HAS 


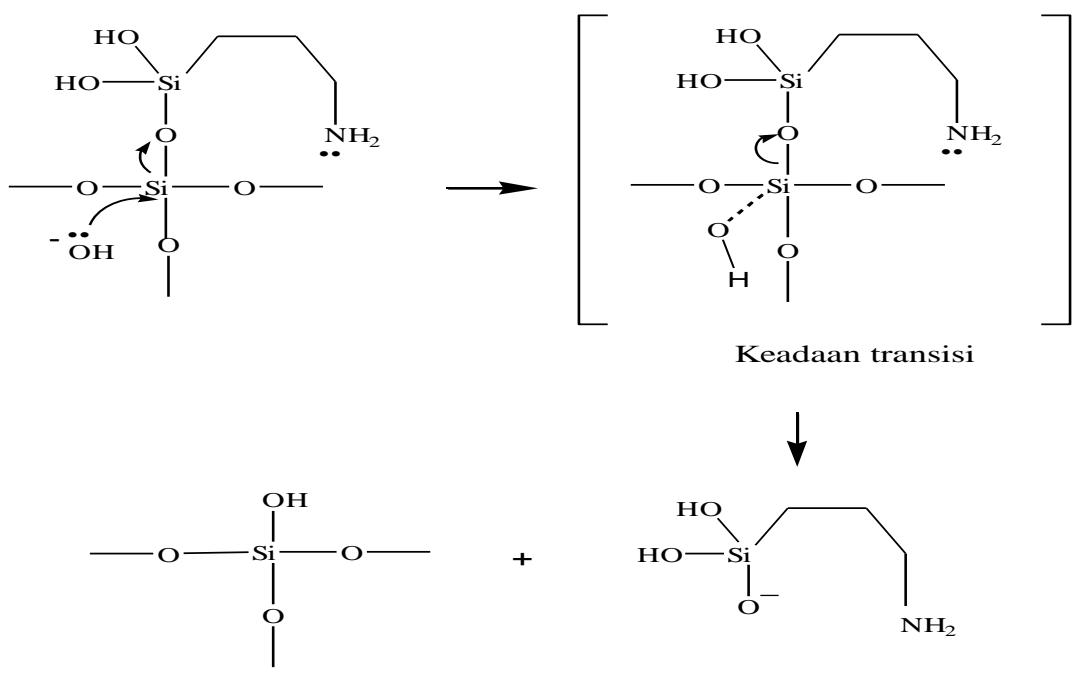

Gambar 2. Reaksi pemecahan HAS membentuk aminopropilsilan

Pada kondisi cukup basa kadar Si tersisa paling sedikit dengan bertambahnya waktu interaksi $(\mathrm{pH}=9,34)$. Jumlah Si terlarut berasal dari hidrolisis jaringan silika dengan pelepasan gugus aminopropilsilan, karena terjadinya hidrolisis pada ikatan kimia antara organosilan dengan permukaan silika. Terdapat indikasi bahwa reaksi pemecahan ikatan tersebut dipengaruhi oleh gugus amina internal pada aminopropilsilan yang cenderung meningkatkan $\mathrm{pH}$ medium air seperti Gambar 2. Reaksi pemecahan tersebut diawali hidrolisis atom $\mathrm{Si}$ pada HAS oleh molekul air yang dipengaruhi oleh gugus amina melalui keadaan transisi dan akhirnya terjadi pemecahan ikatan Siaminopropilsilan dalam HAS tercetak ion menghasilkan aminopropilsilan.

Apabila data kadar Si yang masih tersisa merupakan petunjuk dari stabilitas material $i$ Cd-HAS yang didukung oleh data spektra IR pada Gambar 3, maka dapat dinyatakan bahwa kondisi media asam-basa sangat menentukan kestabilan material tersebut. Dari Gambar 3, tampak bahwa interaksi selama 4 hari memberikan perubahan gugus-gugus fungsional pada $i$-Cd-HAS yang masih tersisa. Perbedaan yang signifikan dalam media asam ditunjukkan dengan adanya serapan tajam pada bilangan gelombang $1381 \mathrm{~cm}^{-1}$ (Gambar 3a) pada media sedikit netral yang menjadi $1411 \mathrm{~cm}^{-1}$ (Gambar 3b) yang bergeser pada media basa menjadi $1404 \mathrm{~cm}^{-1}$ disertai penurunan intensitas serapan yang sangat besar. Pita serapan tajam pada pada bilangan gelombang $1381 \mathrm{~cm}^{-1}$ (Gambar 3a) tersebut muncul sebagai akibat interaksi material dengan asam nitrat, diperkirakan berasal dari serapan ion nitrat yang tersisa (Kloprogge et al., 2002 dan Gonzales et al., 2004), sedangkan pada media sedikit netral dan basa merupakan hasil dari deformasi gugus $\mathrm{NH}_{2}$ menjadi $-\mathrm{NH}_{3}^{+}$(serapan $1450-1600 \mathrm{~cm}^{-1}$ ) akibat deprotonasi gugus silanol yang tersisa 
yang menstabilkan reaksi pada permukaan silika karena adanya gugus amina yang bersifat basa (Walcarius et al., 1999). Selain itu pita serapan yang pada bilangan gelombang $1512,19 \mathrm{~cm}^{-1}$ (berasal dari gugus $-\mathrm{NH}_{2}$ yang mengalami tumpang tindih dengan gugus - $\mathrm{OH}$ dari uap air atau silanol ) pada media asam bergeser ke arah bilangan gelombang yang lebih besar yaitu 1527 $\mathrm{cm}^{-1}$ dan disertai penurunan intensitas yang pada media netral dan basa. Hal ini memberikan petunjuk bahwa makin basa media larutan yang digunakan menyebabkan makin menurunnya stabilitas material $i$-Cd-HAS karena terdegradasinya (pecahnya) ikatan Siaminopropilsilan seperti yang terdapat pada Gambar 2.

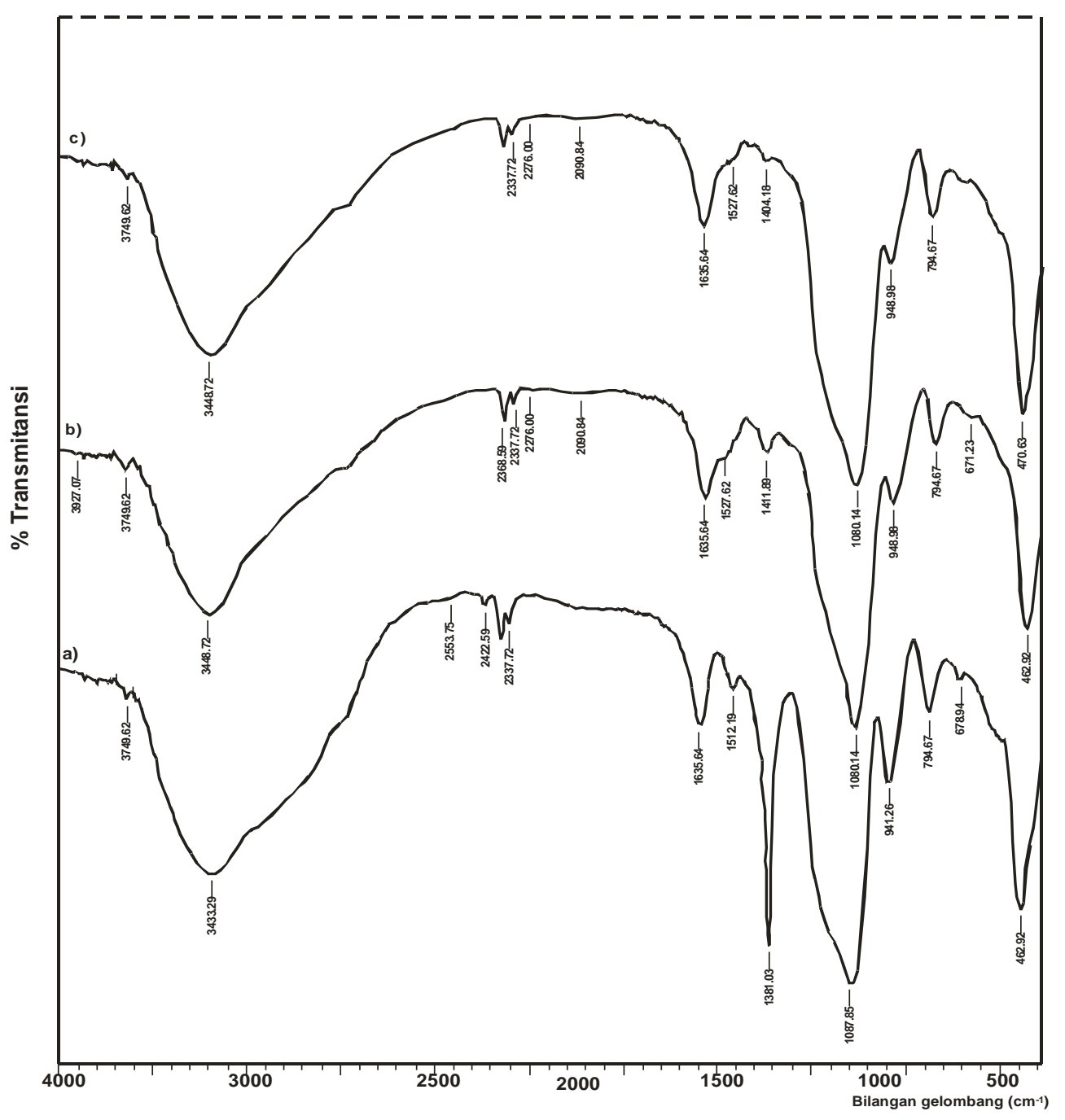

Gambar 3. Spektra IR material $i$-Cd-HAS setelah interaksi 96 jam dengan a) $\mathrm{HNO}_{3} 0,1 \mathrm{M}(\mathrm{pH}=1,35)$, b) $\mathrm{CH}_{3} \mathrm{COONa} 0,1 \mathrm{M}(\mathrm{pH}=5,22)$ dan $\left.\mathrm{c}\right)$ di dalam air $(\mathrm{pH} 9,34)$ 
Gambar 4 yang merupakan hasil spektra IR $i$-Cu-HAS setelah interaksi dengan larutan selama 4 hari teramati bahwa pola serapan material $i$-Cu-HAS setelah waktu interaksi selama 4 hari dengan media larutan tidak menunjukkan adanya gugus aminopropilsilan dengan tidak munculnya serapan pada 2962,66 $\mathrm{cm}^{-1}$ yang merupakan vibrasi ulur dari gugus $\mathrm{CH}_{2}$ yang berasal aminopropilsilan. Pita serapan tajam yang terdapat pada $i$-Cu-HAS dalam media asam (Gambar 4a) yaitu pada bilangan gelombang $1381 \mathrm{~cm}^{-1}$ yang berasal dari ion nitrat yang tersisa (Coates, 2000; Kloprogge et al., 2002; Gonzales et al., 2004) tidak nampak pada material $i$-Cu-HAS dalam media netral (Gambar 4b) dan media basa (4c). Hal ini menunjukkan bahwa gugus fungsional yang terdapat dalam $i$-Cu-HAS mengalami perubahan karena pengaruh media larutan. Seperti yang telah diuraikan sebelumnnya, bahwa pada kondisi basa material HAS relatif kurang stabil dengan meningkatnya $\mathrm{pH}$ larutan. Hal ini didukung pula oleh terjadinya pergeseran bilangan gelombang dan berkurangnya intensitas dari pita $1512 \mathrm{~cm}^{-1}$ pada media asam menjadi $1527 \mathrm{~cm}^{-1}$ (gugus -NH primer tumpang tindih dengan $-\mathrm{OH}$ ) pada media netral dan basa. Pergeseran bilangan ke arah yang lebih besar tersebut menunjukkan bahwa meningkatnya energi yang mengakibatkan menurunnya stabilitas.
Pada kondisi asam $i$-Cd-HAS dan $i$-CuHAS stabil karena adanya protonasi pada gugus $-\mathrm{NH}_{2}$ yang mencegah terjadinya pemutusan ikatan Si-aminopropilsilan. Akan tetapi pada kondisi sedikit netral dan basa, adanya gugus $\mathrm{NH}_{2}$ pada $i$-Cd-HAS dan $i$-Cu-HAS mempercepat kelarutan material tersebut karena gugus $-\mathrm{NH}_{2}$ menyebabkan media larutan menjadi lebih bersifat basa. Pada media netral terdapat spesies $-\mathrm{C}-\mathrm{NH}_{2}$. Hal ini didukung oleh hasil penelitian Etienne dan Walcarius (2003) dengan membandingkan kelarutan silika terhadap HAS dalam medium air, yang menunjukan bahwa jumlah $\mathrm{Si}$ terlarut dalam $\mathrm{mgL}^{-1}$ pada HAS lebih besar dari silika tanpa modifikasi pada waktu interaksi yang sama. Hal ini membuktikan bahwa gugus $-\mathrm{NH}_{2}$ berperan dalam melarutkan $\mathrm{Si}$ yang terdapat dalam material. Pada media netral dengan adanya buffer asetat menunjukkan kelarutan $\mathrm{Si}$ yang relatif lebih kecil dari media basa, hal tersebut terjadi karena adanya buffer asetat menetralkan gugus $-\mathrm{NH}_{2}$ pada $i$-Cd-HAS dan $i$-Cu-HAS.

Data stabilitas material $i$-Cd-HAS dan $i$ $\mathrm{Cu}-\mathrm{HAS}$ pada penelitian ini dibandingkan dengan data pengaruh $\mathrm{pH}$ yang terdapat pada silika tanpa modifikasi (Papirer, 2000) menunjukan bahwa pada silika gel terjadi perubahan situs permukaan karena pengaruh $\mathrm{pH}$ dan berubah sangat tajam pada $\mathrm{pH}>10$. Secara umum dapat dikatakan bahwa muatan negatif meningkat dengan berambahnya $\mathrm{pH}$ larutan 
hingga $\mathrm{pH} 10$, di atas $\mathrm{pH}$ tersebut selanjutnya kenaikan $\mathrm{pH}$ larutan memberikan pengaruh yang relatif lebih kecil terhadap muatan negatif. Pada $i$-Cd-HAS dan $i$-Cu-HAS stabilitas mulai menurun pada $\mathrm{pH}$ yang lebih rendah dari 10 . Hal ini menunjukkan bahwa gugus amina pada $i$-Cd-HAS dan $i$-Cu-HAS berpengaruh terhadap menurunnya stabilitas material tersebut.

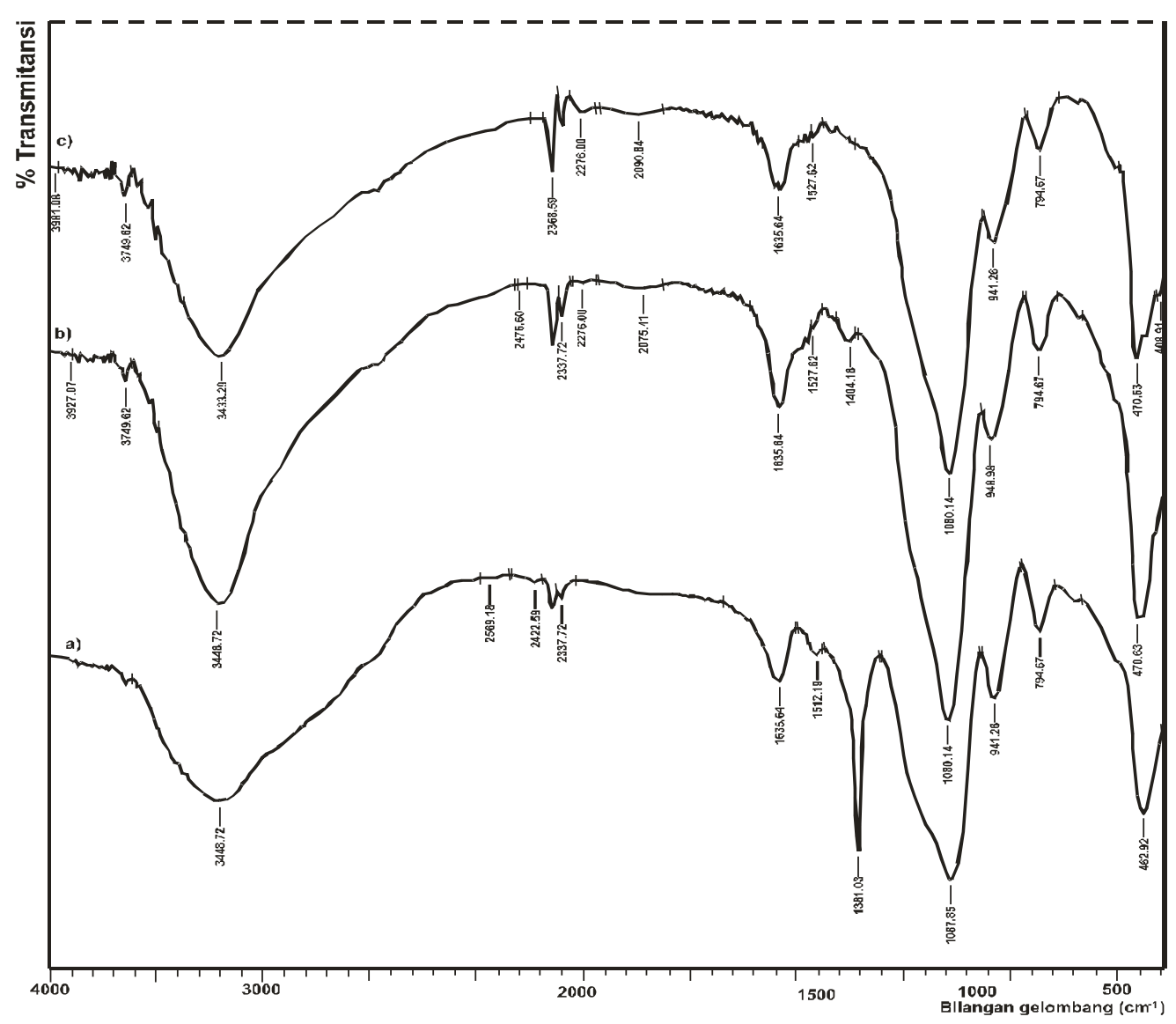

Gambar 4 Spektra IR material $i$-Cu-HAS setelah interaksi 96 jam dengan a) $\left.\mathrm{HNO}_{3} 0,1 \mathrm{M}(\mathrm{pH}=1,35), \mathrm{b}\right)$ $\mathrm{CH}_{3} \mathrm{COONa} 0,1 \mathrm{M}(\mathrm{pH}=5,22)$ dan c) di dalam air $(\mathrm{pH} 9,34)$

Dari data stabilitas $i$-Cd-HAS pada $i$-Cu-HAS $\%$ Si tersisa selama waktu dibandingkan dengan $i$-Cu-HAS dapat diketahui interaksi 4 hari untuk media asam $(81,84 \%)$, bahwa pada kondisi asam dan netral material $i$ - $\quad$ sedikit netral $(36,98 \%)$ dan basa $(7,59 \%)$. Data Cd-HAS relatif lebih stabil dari $i$-Cu-HAS yang kelarutan Si menunjukkan bahwa material $i$-Cdditunjukkan dengan \% Si tersisa setelah waktu HAS dan $i$-Cu-HAS dapat digunakan dalam interaksi selama 4 hari masing-masing untuk $i$ - kondisi netral atau sedikit basa untuk aplikasi Cd-HAS pada media asam $(95,89 \%)$, sedikit kompleks dari gugus amina dalam jangka waktu netral $(43,82 \%)$ dan basa $(9,39 \%)$. Sedangkan yang pendek (beberapa jam eksperimen). Pada 
kondisi media asam material dapat digunakan dalam jangka panjang (beberapa hari) dalam bentuk terprotonasi.

\section{Kesimpulan}

Pada kondisi asam dan netral material $i$ Cd-HAS relatif lebih stabil dari $i$-Cu-HAS yang ditunjukkan dengan \% Si tersisa setelah waktu interaksi selama 4 hari. Material $i$-Cd-HAS dan $i$-Cu-HAS stabil pada media asam karena adanya protonasi pada gugus amina dan tidak stabil pada media basa karena pecahnya ikatan Si-aminopropilsilan yang dipengaruhi oleh gugus amina.

\section{Daftar Pustaka}

Alcantara, E.F.C, Faria, E.A., Rodrigues, D.V., Evangelista, S.M., De Oliveira, E., Zara, L.F., Rabelo, D., and Prado, A.G.S, 2007, Modification of Silica Gel by Attachment of 2Mercaptobenzimidazole for Use in Removing $\mathrm{Hg}$ (II) from Aqueous Media : A Thermodynamic Approach, J. Colloid and Interface Sci., 311: 1-7.

Buhani, Narsito, Nuryono and Kunarti, E.S., 2009, Amino and Mercapto-Silica Hybrid for $\mathrm{Cd}(\mathrm{II})$ Adsorption in Aqueous Solution, Indo .J. Chem., 9 (2): 170-176.

Buhani, Narsito, Nuryono dan Kunarti, E.S., 2010, Production of Metal Ion Imprinted Polymer from Mercapto-Silica through Sol-Gel Process as Selective Adsorbent of Cadmium, Desalination, 251 : 83-89.
Camel, V., 2003, Solid Phase Extraction of Trace Elements, Spectrochim. Acta Part $B, 58: 1177-1233$.

Chiron, N., Guilet, R., and Deydier, E., 2003, Adsorption of $\mathrm{Cu}(\mathrm{II})$ and $\mathrm{Pb}(\mathrm{II})$ onto Grafted Silica: Isotherms and Kinetic Models, Water Res., 37: 3079-3086.

Coates, J. 2000, Interpretation of Infrared Spectra, A Practical Approach in Encylopedia of Analytical Chemistry, John Wiley \& Sons Ltd, Chichester p: $10815-10837$.

Cui, Y., Chang, X., Zhu, X., Luo, H., Hu, Z., Zou, X, He, Q., 2007, Chemically Modified Silica Gel with pdimethylaminobenzaldehyde for Selective Solid-Phase Extraction and Preconcentration of $\mathrm{Cr}(\mathrm{III}), \mathrm{Cu}(\mathrm{II})$, $\mathrm{Ni}(\mathrm{II}), \mathrm{Pb}(\mathrm{II})$ and $\mathrm{Zn}(\mathrm{II})$ by ICP-OES, Microchem. J., 8: 20-26.

Etienne, M., and Walcarius, A., 2003, Analytical Investigation of Chemical Reactivity and Stability of Aminopropyl Grafted Silica in Aqueous Medium, Talanta, 59: 1173-1188.

Gonzales, O.Q., Burell, J.C.L., Martinez, E., Barrera, C., Acosta, R.M, and Ruiz, N., 2004, Obtaining, Characterization and Thermal Decomposition of Barium Nitrate, Revista Cubana Quimica, 16(1): 44-52.

Hajiaghababaei, L., Badiei, A., Ganjali, M.R., Heydari, S., Khaniani, Y., Ziarani, G.M., 2011, Highly Efficient Removal and Preconcentration of Lead and Cadmium Cations from Water and Wastewater Samples Using Ethylenediamine Functionalized SBA-15, Desalination, 266, 182-187.

HyvÖnen, H., 2008, Studies on Metal Complex Formation of Environmentally Friendly 
Aminopolycarboxylate Chelating Agents, Dissertation, Faculty of Science Universitas of Helsinki, Finland.

Jiang, N., Chang, X., Zheng, H., He, Q., and $\mathrm{Hu}, \mathrm{Z} ., 2$ 2006, Selective Solid-Phase

Extraction of Nickel(II) Using a SurfaceImprinted Silica Gel Sorbent, Anal.

Chim. Acta, 577: 225-231.

Kloprogge, J.T, Wharton, D, Hickey, L., and Frost, R.L., 2002, Infrared and Raman Study of Interlayer anion $\mathrm{CO}_{3}{ }^{2-}, \mathrm{NO}_{3}{ }^{-}$ and $\mathrm{ClO}_{4}^{-}$in $\mathrm{Mg} / \mathrm{Al}-\mathrm{Hydrotalcite}$, American Mineralogist, 87(5-6): 623629.

Papirer, E., 2000, Adsorption on Silica Surface, Marcel Dekker, New York.

Walcarius, A., Etienne., M., and Bessiere, J., 2002, Rate of Access to the Binding Sites in Organically Modified Silicates 1. Amorphous Silica Gels Grafted with Amine or Tiol Groups, Chem. Matter, 14: 2757-2766.

Zhai, Y., Liu, Y., Chang, X., Ruan, X., and Liu, J., 2008, Metal Ion-Small Molecule Complex Imprinted Polymer Membranes: Preparation and Separation Characteristics, React. \& Funct. Polymers , 68: 284-291.

Zhao, J., Han, B., Zhang, Y., and Wang, D., 2007, Synthesis of Zn(II) Ion-Imprinted Solid-Phase Extraction Materials and Its Analytical Application, Anal. Chim. Acta, 603: 87-92. 